\title{
Diel changes of food sources and their contributions to nutrition of Orientomysis mitsukurii in a sandy shore environment
}

\author{
Kazutaka Takahashi ${ }^{1, *}$, Akira Kuwata ${ }^{2}$, Takeo Suzuki ${ }^{3}$, Tatsuki Toda ${ }^{3}$, Keiichiro Ide ${ }^{2}$ \\ ${ }^{1}$ Department of Aquatic Bioscience, Graduate School of Agricultural and Life Sciences, The University of Tokyo, \\ Tokyo 113-8657, Japan \\ ${ }^{2}$ Tohoku National Fisheries Research Institute, 3-27-5 Shinhama-cho, Shiogama, 985-0001, Japan \\ ${ }^{3}$ Faculty of Engineering, Soka University, 1-236 Tangi-cho, Hachioji, Tokyo 192-8577, Japan
}

\begin{abstract}
Diel changes in feeding habits and the relative contributions of daytime and nighttime diets to the nutrition of the mysid Orientomysis mitsukurii in a sandy shore environment were determined by field sampling and additional laboratory experiments. O. mitsukurii was distributed just above the bottom during the daytime but a subpopulation swam up into the water column at night. Nighttime swimming activity was prevalent in small individuals but progressively decreased at larger body sizes, while the gut pigment contents of all mysid size classes consistently increased at night. Stomach content analysis revealed that $O$. mitsukurii individuals of all size groups ingested sedimented particulate organic matter (POM) containing large quantities of clay minerals during the daytime, whereas they mainly foraged on planktonic diatoms in the water column at night. Estimated in situ algal ingestion rates at night accounted for approximately $80-95 \%$ of the daily carbon assimilation. O. mitsukurii also exhibited high efficiency in grazing on planktonic diatoms in laboratory experiments. Conversely, daytime sedimented POM carbon accounted for only a minor proportion (5-20\%) of the daily carbon assimilation. The utilisation patterns of the different food sources were confirmed by carbon and nitrogen stable isotopic signatures in the benthic community. Our results suggest that efficient utilisation of primary producers, such as planktonic diatoms, by $O$. mitsukurii is beneficial for maintaining the species' high abundance from an ecological transfer efficiency perspective, and that sedimented POM is an alternative food source for securing the basic energy required for their survival, particularly when phytoplankton availability is low.
\end{abstract}

KEY WORDS: Mysidae $\cdot$ Omnivore $\cdot$ Nighttime feeding $\cdot$ Vertical migration $\cdot$ Sandy shore environment $\cdot$ Detritus $\cdot$ Diatoms

\section{INTRODUCTION}

Mysids are a dominant component of various coastal ecosystems and often constitute the dominant prey items of commercially important fish species and crustaceans (Mauchline 1980, Möllmann et al. 2004, Cartes et al. 2008, 2009, Latour et al. 2008). One of the most notable ecological characteristics of coastal mysids is their flexible feeding behaviour. Most mysids are omnivores and feed upon a wide range of food items, including rotifers, copepods, cladocerans,

\footnotetext{
*Corresponding author: akazutak@mail.ecc.u-tokyo.ac.jp
}

amphipods, and carrion as well as detritus, diatoms, and fragments of terrestrial plants, seeds, and macroalgae (Froneman 2001, Viherluoto \& Viitasalo 2001, Takahashi 2004, Lehtiniemi \& Nordström 2008, Vilas et al. 2008, Takahashi et al. 2015). Such feeding habits indicate that mysids play an important role in the grazing and detrital food chains, and this is advantageous for maintaining their biomass in coastal habitats.

Orientomysis mitsukurii (formerly known as Acanthomysis mitsukurii) is abundant in sandy shore

() The authors 2017. Open Access under Creative Commons by Attribution Licence. Use, distribution and reproduction are unrestricted. Authors and original publication must be credited. 
environments along the Pacific coastline of northeastern Japan (Yamada et al. 1994). This species is the main prey of juvenile Japanese flounder Paralichthys olivaceus (Yamada et al. 1998a,b, Tomiyama et al. 2011) and of various demersal fish that live along this coastline (Katayama et al. 2008, Tomiyama et al. 2013). Therefore, O. mitsukurii plays an essential role in the carrying capacity of these regions, which are important nursery areas for a variety of commercial fish species (Tomiyama et al. 2013). Despite the importance of this species to coastal ecosystems, the contributions of different food sources to the diet and biomass of $O$. mitsukurii have not been studied in detail. A study by Yamada et al. (1995) demonstrated that $O$. mitsukurii individuals collected from the field contained both benthic diatoms and detrital material. From an energy budget perspective, Yamada (2000) suggested that plants, including benthic diatoms, were insufficient to meet the metabolic energy requirements of this mysid species, and emphasised the importance of other food sources in its diet, such as unclassified detritus-like materials, which constitute the majority of its stomach contents. $\mathrm{He}$ also found that the gut pigment contents of this species increased at night (Yamada 2000), although this diel change was not examined in detail.

In the present study, we investigated the contributions of different food sources to the diet of O. mitsukurii in a shallow, sandy shore environment in northeastern Japan in order to increase our understanding of the trophic base of fish production in this region. We conducted $24 \mathrm{~h}$ field samplings to investigate diel changes in the diet, in addition to laboratory experiments, to quantify the relative dietary importance of plants and unidentified detritus-like material. Our results indicate that $O$. mitsukurii is able to utilise 2 different food sources efficiently throughout the diel cycle, which is probably how it maintains high abundances during the summer.

\section{MATERIALS AND METHODS}

\section{Sampling sites}

The study was conducted along the sandy shore environment of the Pacific coastline of northeastern Japan during the summer, which is the main recruitment and post-settlement period for Japanese flounder in this region (Yamada et al. 1998b). Diel changes in the distribution and diet composition of Orientomysis mitsukurii in the field were investigated at
Ukedo-hama $\left(37^{\circ} 28^{\prime} \mathrm{N}, 141^{\circ} 04^{\prime} \mathrm{E}\right)$, Fukushima Prefecture, where it was suitable to conduct $24 \mathrm{~h}$ sampling because a small port that could harbour a research boat was located near the sampling site. Additional specimens for laboratory experiments and stable isotope analysis were collected at Ara-hama $\left(38^{\circ} 08^{\prime} \mathrm{N}, 140^{\circ} 59^{\prime} \mathrm{E}\right)$, Miyagi Prefecture, which was the closest sampling site to a laboratory (Tohoku National Fisheries Research Institute) (Fig. 1). Although the sampling sites were approximately $70 \mathrm{~km}$ apart, they had similar environmental characteristics, both being open sandy beaches exposed to the Pacific Ocean. A previous survey of this region revealed that O. mitsukurii occur at both sampling sites in high numbers (Yamada et al. 1994).

\section{Field sampling for distribution and feeding habits}

Diel changes in the vertical distributions, food items and gut pigment contents of $O$. mitsukurii in the field were determined every $3-4 \mathrm{~h}$ from 14:00 $\mathrm{h}$ on 23 July until 14:00 h on 24 July 2001 (Fig. 1). The weather was sunny and clear, and the sea conditions were calm throughout the sampling period. Sunset was at 18:36 $\mathrm{h}$ and sunrise at 04:33 $\mathrm{h}$. The moon was in the last quarter phase and low tide occurred at $23: 42 \mathrm{~h}$ and 12:17 $\mathrm{h}$ and high tide at 18:36 $\mathrm{h}$ and 05:17 $\mathrm{h}$, with a maximum tidal range of $135 \mathrm{~cm}$ (MSA 2001). A sledge net ( $60 \mathrm{~cm}$ wide, $40 \mathrm{~cm}$ high, $200 \mu \mathrm{m}$ mesh) was employed to investigate the benthic distribution of $O$. mitsukurii. Sampling was conducted along a $100 \mathrm{~m}$ transect line that was marked with buoys parallel to the shoreline (9 $\mathrm{m}$ deep at high tide). A conical plankton net with a $30 \mathrm{~cm}$ mouth diameter and $330 \mu \mathrm{m}$ mesh was also towed horizontally along the transect line to collect mysids swimming in the water column. The difference in mesh size between the sledge net and the conical plankton net could not affect the sampling efficiency of $O$. mitsukurii, as its minimum body width (ca. 500-600 $\mu \mathrm{m}$ ) is larger than $330 \mu \mathrm{m}$ and no net clogging occurred during sampling. The water column layers sampled were surface, middle ( $3.5 \mathrm{~m}$ above the bottom), and nearbottom (1.5 m above the bottom). Attachment positions of the plankton nets onto the wire were preset based on the desired sampling depth and the wire angle, which was maintained at $45^{\circ}$ during each haul. When the nets were lowered and retrieved, the wire was kept vertical to minimise sampling contamination from undesired layers. Samples were frozen in dry ice within 10 min of collection, transferred to a freezer in the laboratory and maintained at $-80^{\circ} \mathrm{C}$ until analysis. 


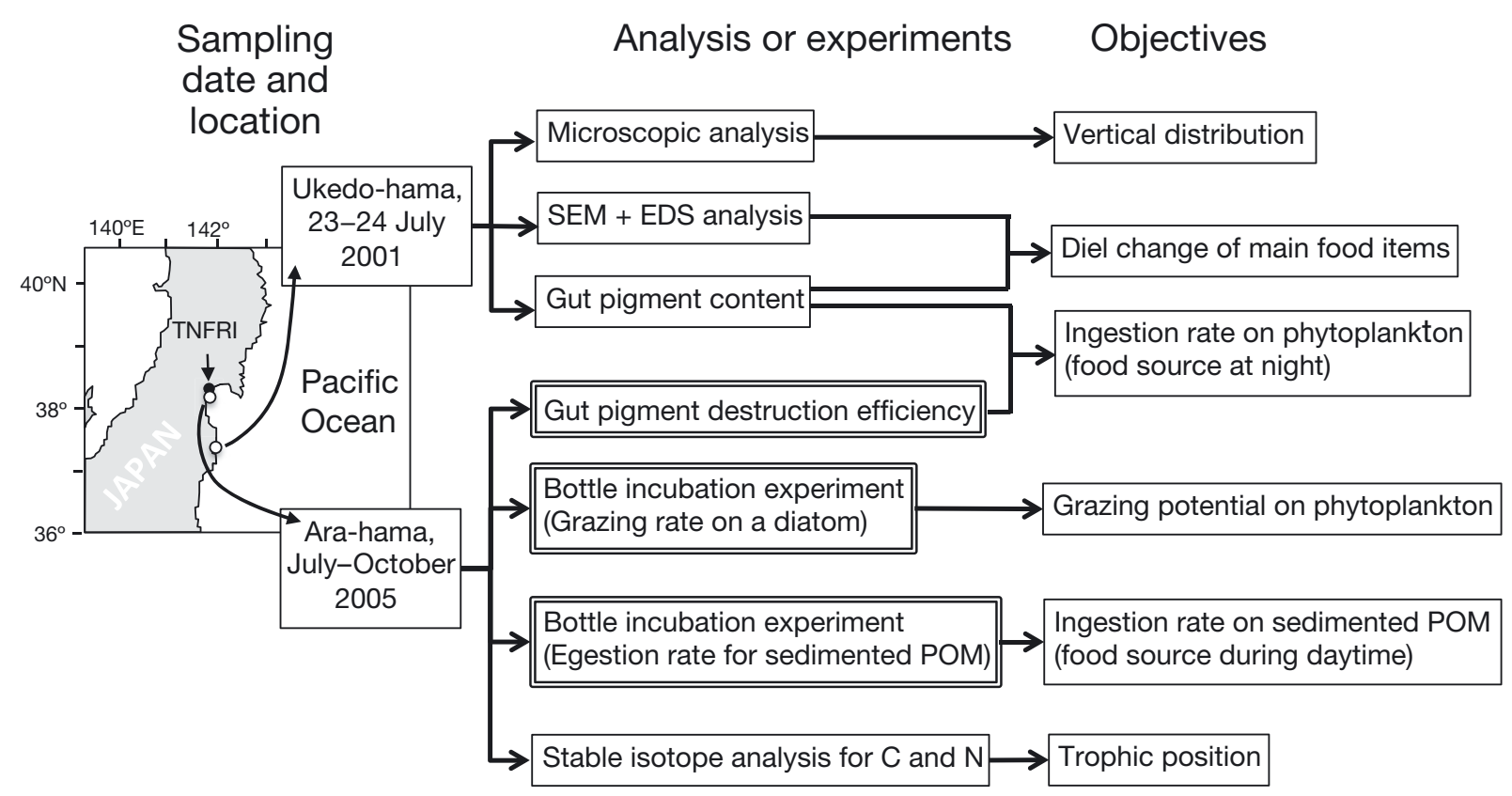

Fig. 1. Sampling sites for Orientomysis mitsukurii and flow diagram of analyses and experiments for the respective objectives of the study. Boxes bordered with double lines indicate incubation experiments in the laboratory. TNFRI: the location of the laboratory at the Tohoku National Fisheries Research Institute, where the experiments were conducted. SEM: scanning electron microscopy; EDS: energy dispersive spectrometry

Temperature and salinity were measured in the field using a TS-meter (ACT20D; Alec Electronics) at midnight $(00: 00 \mathrm{~h})$ and at 13:00 h. Phytoplankton samples were collected at the same time using a Van Dorn sampler from the surface layer, middle layer, nearbottom layer, and $0.5 \mathrm{~m}$ above the bottom layer, and preserved with a $3 \%$ acid-Lugol's solution.

\section{Microscopic analysis}

In the laboratory, the frozen samples collected in the field were thawed using chilled, filtered seawater. Using a dissecting microscope (Leica MZ16) in dim light, individuals of $O$. mitsukurii were sexed and assigned to different developmental (maturity) stages according to Mauchline (1980) and then counted and stored in chilled glass vials for later analysis (scanning electron microscope [SEM] and gut pigments). The remainder of the samples were preserved in formalin seawater for enumeration and sizing. The body length $(\mathrm{BL}$; distance in $\mathrm{mm}$ from the base of the eyestalk to the end of telson) was measured using a dissecting microscope with a calibrated eyepiece reticle micrometre. O. mitsukurii density in each sampled water column layer was expressed as number per unit volume $\left(\mathrm{m}^{3}\right)$ based on the net opening area and the towing distance, assuming a sampling efficiency of 1.0. Quantification of diatoms and dinoflagellates was conducted using an inverted microscope (Leica DM IRBE) by Utermöhl's (1958) method.

\section{Analysis of food items by SEM}

Stomach (foregut) contents of the mysids were determined using SEM on the frozen specimens (Fig. 1). Specimens were fixed in $4 \%$ glutaraldehyde immediately after thawing. Under a dissecting microscope, the stomach was carefully removed and separated into 2 parts by the dry fracturing method (Toda et al. 1989), coated with gold, and examined by SEM (JSM-5600LV; JEOL). Stomach contents of mysids collected from the bottom during daytime $(13: 00 \mathrm{~h}$, $\mathrm{n}=11$ individuals) and nighttime $(00: 00 \mathrm{~h}, \mathrm{n}=14)$, and from the surface layer of the water column during nighttime $(00: 00 \mathrm{~h}, \mathrm{n}=12)$ were identified, and the frequency of occurrence of each food item was recorded. The BL of the mysids used to determine the general feeding habits of the population ranged from 2.2 to $7.3 \mathrm{~mm}$. Further characterisation of stomach contents (namely elemental compositions of $\mathrm{Si}$ and $\mathrm{Al}$ as indicators of diatoms and inorganic sediment, respectively; Iwamoto et al. 2009) was performed by energy dispersive spectrometry (EDS) analysis, using the EX-23000BU (JEOL) system. 


\section{Gut pigment contents}

As an index of their feeding intensity on algae, diel changes in the gut pigment content of O. mitsukurii were determined in the frozen specimens (Mackas \& Bohrer 1976). Immediately after thawing, specimens were rinsed with filtered seawater and then dipped into $4 \mathrm{ml}$ of $\mathrm{N}, \mathrm{N}$-dimethylformamide to extract the gut pigments. Between 7 and 43 extraction bottles were prepared for each sampling time and depth stratum, depending on the number of O. mitsukurii individuals in the samples. Extraction bottles were maintained at $-20^{\circ} \mathrm{C}$ in darkness until analysis (>24 h). Pigment concentrations were measured using a Turner Designs fluorometer (10-AU-005). The gut pigment content was expressed as chlorophyll a (chl a) + phaeopigments in a chl a equivalentweight per individual.

\section{Gut pigment destruction efficiency}

Gut pigment destruction efficiency was determined in the laboratory using the 2-component approach (Perissinotto 1992). Mysids were collected with the sledge net at Ara-hama (Fig. 1) during the day on 14 July and 19 August 2005. Healthy and intact $O$. mitsukurii were carefully selected from the bulk plankton sample and pre-incubated at $18^{\circ} \mathrm{C}$ for $24 \mathrm{~h}$ in filtered seawater, to which cornstarch had been added. Four to 5 replicate bottles $(250 \mathrm{ml})$, each containing 2 mysids, were incubated on a plankton wheel with a suspension containing the cultured diatom Leptocylindrus danicus, which commonly occurs at the sampling site. Four control bottles without mysids were also incubated. After $30 \mathrm{~min}$, the mysids were collected with an $80 \mu \mathrm{m}$ sieve for gut pigment analysis using the same methods as described above. An aliquot of algal suspension (100 $\mathrm{ml}$ ) from the experimental and control bottles was filtered onto glass microfibre filters (grade GF/F) and the chl a concentration was measured using a Turner Designs fluorometer after extraction with N,Ndimethylformamide (Suzuki \& Ishimaru 1990). A comparison of pigment budgets between control and experimental bottles was then conducted to estimate actual grazing by mysids, and any significant loss in the pigment budget from the experimental bottles was attributed to the gut destruction of phytoplankton pigments. All of the experiments were conducted after sunset (19:20-20:00 h), and no faecal pellets were observed in the experimental bottles after the incubation period.

\section{Ingestion rate of phytoplankton in the field}

In situ ingestion was estimated for different size classes of $O$. mitsukurii based on diel changes in mean gut pigment contents and the results of the previously described experiments (Fig. 1). Ingestion rates $\left(I_{i}\right.$ ng pigment mysid $^{-1}$ night $^{-1}$ ) were estimated using the following equation (Perissinotto 1992, Froneman 2001):

$$
I=k G /(1-b)
$$

where $G$ is the integrated value during the nighttime (12 h) of gut pigments (ng mysid ${ }^{-1}$ night $^{-1}$ ), $k$ is the gut evacuation rate, and $b$ is the gut pigment destruction efficiency. I was converted to carbon ingestion rates using a $\mathrm{C} / \mathrm{chl}$ a ratio of representative values of phytoplankton, i.e. 50 (Dagg \& Grill 1980). Evacuation rates were estimated from the mysid BLs using the equation determined by Ritz (2008), which was established for various crustaceans (including mysids) based on direct measurements of gut passage times.

\section{Bottle incubation experiments}

Feeding on diatoms was directly measured using bottle incubations in the laboratory, in order to evaluate the grazing potential of $O$. mitsukurii on phytoplankton (Fig. 1). The O. mitsukurii individuals used in these experiments were collected at Ara-hama during the daytime with the sledge net in July and August 2005, and healthy individuals were preincubated for $24 \mathrm{~h}$ for acclimation with natural seawater collected from the near-bottom layer at the sampling site. After the pre-incubation period, 2 mysids were placed into each of 4 polycarbonate bottles (1.2 l) containing a suspension of the cultured diatom L. danicus, at ca. 60, 300, 1200, and 15000 cells $\mathrm{ml}^{-1}$. The 2 highest concentrations were prepared in order to examine the grazing potential of mysids, and to determine the saturation point of the grazing rate. Two bottles containing diatoms without mysids served as controls. All bottles were incubated on a plankton wheel set at $0.5 \mathrm{rpm}$ under dark condition at $18^{\circ} \mathrm{C}$ for $10 \mathrm{~h}$ during the night (18:00-04:00 h). Algal concentrations at the beginning and end of the experiments were determined using an inverted microscope (Leica DM IRBE); $500 \mathrm{ml}$ of algal suspension was preserved in a $3 \%$ acid-Lugol's solution, and 10-100 ml subsamples were placed in sedimentation chambers (Utermöhl 1958). After allowing the plankton to settle for $24 \mathrm{~h}$, diatoms were counted 
using the inverted microscope under a bright-field. Clearance and ingestion rates were calculated based on the equations provided in Frost (1972). Aliquots of algal suspensions $(200 \mathrm{ml})$ from the control bottles were also filtered onto combusted $\left(450^{\circ} \mathrm{C}, 5 \mathrm{~h}\right) \mathrm{GF} / \mathrm{F}$ filters to determine the carbon content of the diatoms. The filters were then dried at $60^{\circ} \mathrm{C}$ for $48 \mathrm{~h}$, and the carbon content was measured using an elemental analyser (FLASH 2000; Thermo Scientific). An 80\% assimilation efficiency of diatoms was assumed, which is the commonly used value for algae in the diet of mysids (Takahashi 2004).

Because the stomach content analysis revealed that the mysids mainly consumed sedimented particulate organic matter (POM) deposited on the bottom substrate during the daytime, we also estimated the ingestion rates of sedimented POM from egestion rates (faecal pellet production). The O. mitsukurii individuals used in these experiments were collected from Ara-hama on 8 October 2005 using the sledge net. Natural seawater samples containing sedimented POM were collected using a Van Dorn sampler from immediately above the bottom substrate at the same site. The water sampler was intentionally allowed to touch the seafloor several times to ensure that resuspended sedimented POM was collected. Healthy adult mysids were pre-incubated at $18^{\circ} \mathrm{C}$ for $24 \mathrm{~h}$ with the natural seawater. Egestion experiments were conducted in $900 \mathrm{ml}$ airtight tissue culture flasks filled with natural seawater, after removing any large grazers with a $200 \mu \mathrm{m}$ mesh sieve. The sedimented POM was allowed to settle at the bottom of the incubation chambers prior to the beginning of the experiments, and approximately 2-4 adult O. mitsukurii were gently introduced and incubated for $12 \mathrm{~h}$ under dim light conditions at $18^{\circ} \mathrm{C}$. All experiments were conducted during the daytime. Prior to the experiments, an aliquot $(50 \mathrm{ml})$ of natural seawater was filtered through combusted GF/F filters for total carbon analysis using the elemental analyser. At the completion of each experiment, faecal pellets were gently collected with a $200 \mu \mathrm{m}$ mesh sieve and placed onto pre-combusted and pre-weighed GF/F filters after a brief rinsing with distilled water. The filters were dried at $60^{\circ} \mathrm{C}$ for $48 \mathrm{~h}$ and weighed on a Cahn C-32 microbalance to a precision of $0.1 \mu \mathrm{g}$ to obtain dry weights. The dried filters were ashed at $450^{\circ} \mathrm{C}$ for $4 \mathrm{~h}$ and then re-weighed for the determination of the ash free dry weight (AFDW). Filters with sedimented POM from the initial samples were also dried, weighed, and ashed using the same procedure. Ingestion rates of sedimented POM (I were calculated using the following equation:

$$
I_{\mathrm{POM}}=\left[E_{\mathrm{fp}} \times\left(1-C_{\mathrm{PM}}\right)\right] /(1-\mathrm{AE})
$$

where $E_{\mathrm{fp}}$ is the egestion rate of a mysid, i.e. the weight of faecal pellet produced by a mysid per hour $\left(\mu \mathrm{gAFDW}\right.$ mysid $\left.^{-1} \mathrm{~h}^{-1}\right) ; C_{\mathrm{PM}}$ is the fraction of carbon content of the peritrophic membrane in a mysid faecal pellet, i.e. 0.029 (Johnston \& Lasenby 1982); and $\mathrm{AE}$ is the assimilation efficiency (35\%), as reported for Neomysis integer feeding on organic matter in sediments (Roast et al. 2000). I POM was then converted to the carbon ingestion rate $\left(\mu \mathrm{gC}\right.$ mysid $^{-1}$ $\mathrm{h}^{-1}$ ) using a factor of 0.045 , which is the fraction of organic carbon content determined from field-sedimented POM samples (K. Takahashi unpubl. data). An aliquot of sedimented POM sample was also preserved in $4 \%$ glutaraldehyde for later SEM using the low-vacuum SEM freeze drying technique (Suzuki et al. 1995) in order to observe the 3-dimensional structure of the sedimented POM.

\section{Stable isotope ratio analysis}

Stable isotope ratios of carbon and nitrogen were analysed to investigate the food sources of the mysids and the food web structure at the study site (Fig. 1). Benthic animals including mysids were collected at Ara-hama during the daytime in October 2005 using the sledge net. In the laboratory, the animals were sorted in filtered, chilled seawater into taxonomic groups, placed onto pre-combusted GF/C filters, freeze-dried for $24 \mathrm{~h}$, and then ground into a powder with a mortar and pestle. Seston, including suspended living and non-living particles, was collected from $0.5 \mathrm{~m}$ above the bottom with a Van Dorn sampler. Water samples were pre-filtered through a $200 \mu \mathrm{m}$ mesh sieve and particles in the filtrate (10 l) were concentrated onto a pre-combusted GF/F filter and freeze-dried for $24 \mathrm{~h}$ after treatment with $1 \mathrm{M}$ $\mathrm{HCl}$ to remove carbonates. The stable carbon and nitrogen isotope ratios $\left(\delta^{13} \mathrm{C}\right.$ and $\left.\delta^{15} \mathrm{~N}\right)$ were analysed in triplicate using an EA-1108 elemental analyser (Carlo Erba) combined with an isotope ratio mass spectrometer (Finnigan Mat ConFlo II, Mat 252). The isotope ratios are expressed as a per million (\%) deviation from international standards (i.e. Pee Dee Belemnite and atmospheric $\mathrm{N}_{2}$ ): $\delta^{13} \mathrm{C}, \delta^{15} \mathrm{~N}=1000$ ( $\left.R_{\text {sample }}-R_{\text {standard }}\right) R_{\text {standard1, where } R \text { is }{ }^{13} \mathrm{C} /{ }^{12} \mathrm{C} \text { and }}$ ${ }^{15} \mathrm{~N} /{ }^{14} \mathrm{~N}$. The analytical precision of the instrument was $0.2 \%$. Trophic relationships were examined using a biplot of $\delta^{13} \mathrm{C}-\delta^{15} \mathrm{~N}$ values for seston and benthic organisms including $O$. mitsukurii. As a comparison, isotopic signatures of possible food sources, 
e.g. planktonic diatoms, benthic diatoms, and sedimentary organic matter, which were observed near the sampling site, were also used in the analysis (Ito 2002, Ganbe et al. 2014).

\section{RESULTS}

\section{Diel changes in vertical distributions and feeding habits in the field}

During field sampling, the temperature was consistently highest at the surface, varying between $21.0-21.8^{\circ} \mathrm{C}$, and decreased with depth to $16.5-19.8^{\circ} \mathrm{C}$ in the bottom layer (Fig. 2A). Overall, the water column temperature was higher during the daytime than at night. Salinity was variable at the surface, ranging between 32.9 and 33.1, while it was relatively stable
(33.2-33.3) from the bottom up to $4 \mathrm{~m}$ depth (Fig. 2B). Regardless of sampling time, diatoms were most abundantly distributed $0.5 \mathrm{~m}$ above the bottom layer and were less frequent in the upper water column, while dinoflagellates were less frequent throughout the entire water column (Fig. 2C). Microscopic analysis revealed that the planktonic diatom species Leptocylindrus danicus and Rhizosolenia setigera, and the benthic diatom species Cylindrotheca closterium and Navicula spp. were abundant.

Orientomysis mitsukurii was exclusively distributed just above the bottom during the daytime, with no individuals collected within the water column (Fig. 2D). At night, a proportion of the population swam up to the water column with variable density (20-480 ind. $\mathrm{m}^{-3}$ ), although a substantial number of individuals (ca. 200 ind. $\mathrm{m}^{-3}$ ) constantly remained near the bottom (Fig. 2D). The highest density during
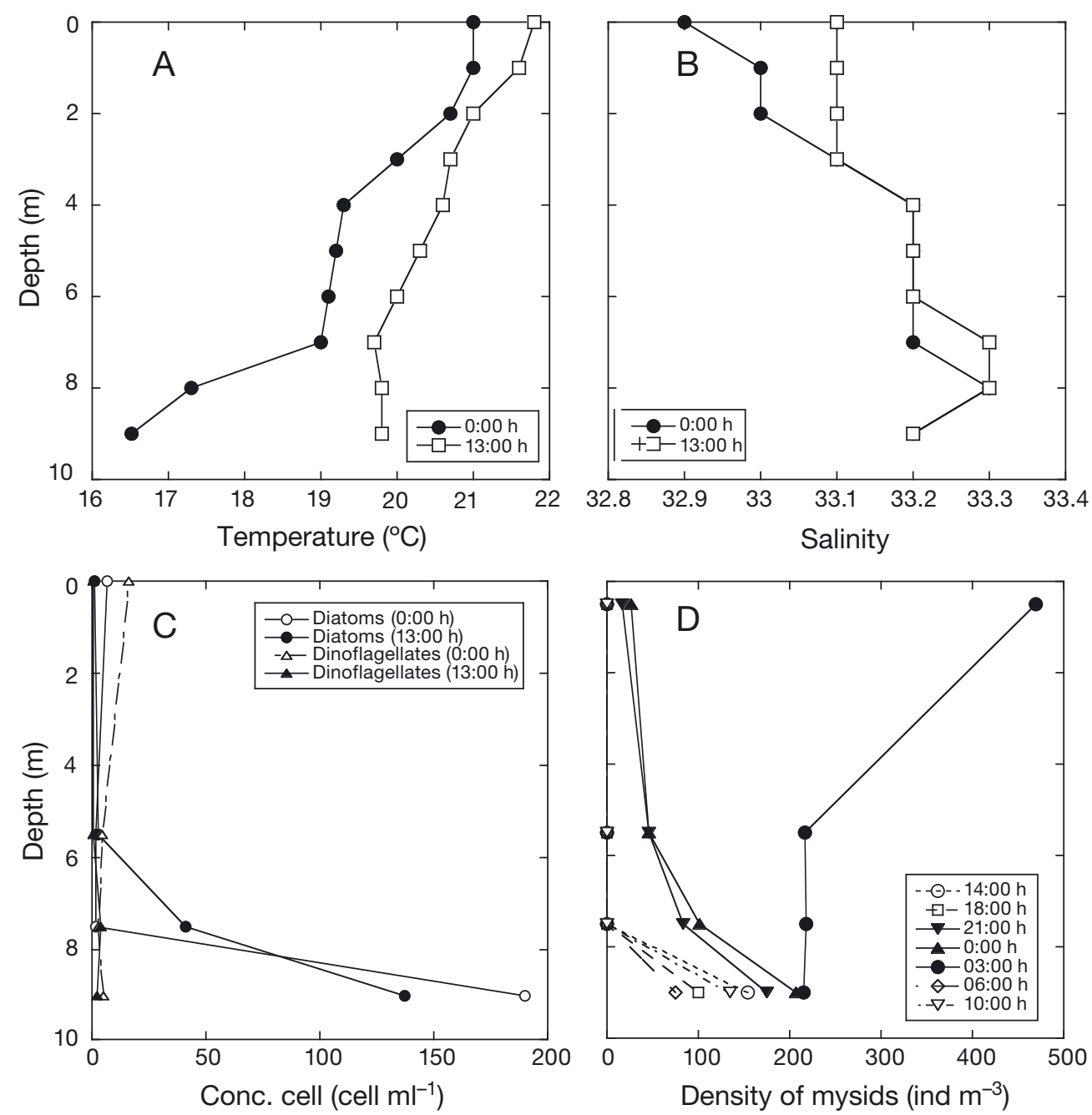

Fig. 2. Diel changes in (A) temperature and (B) salinity, and vertical distribution of (C) phytoplankton and (D) Orientomysis mitsukurii at the sampling site at Ukedo-hama 
nighttime in the water column was observed at 03:00 $\mathrm{h}$, when mysid density in the surface layer was 2.5 times greater than that in the remainder of the water column (Fig. 2D). In general, the nighttime swimming population consisted of small individuals with mean BL of approximately 2.0-3.5 mm (Fig. 3). The upward migration observed at 03:00 $\mathrm{h}$ was achieved via abrupt increases in the density of small individuals at the surface layer, while the mean BL of individuals in the surface layer during the first half of the night was slightly greater than that of individuals in the water column (Fig. 3).

The gut pigment contents of O. mitsukurii generally increased in the nighttime samples, regardless of size or sex (Fig. 4). Mean gut pigment contents of all developmental stages had increased by over 3 -fold by 21:00 $\mathrm{h}$ compared to those at 18:00 $\mathrm{h}$. This increase was evident in immature individuals and adults collected at bottom, while high gut pigment contents in juveniles were found in the surface layer (Fig. 3). The gut pigment contents slightly decreased at midnight in all developmental stages, and a second peak before dawn (03:00 h) was observed in juveniles and small immature individuals, although a corresponding peak was not observed in larger immature individuals or adults.

Although the stomachs of all the O. mitsukurii individuals examined with SEM were full of food items regardless of sampling time, their contents exhibited

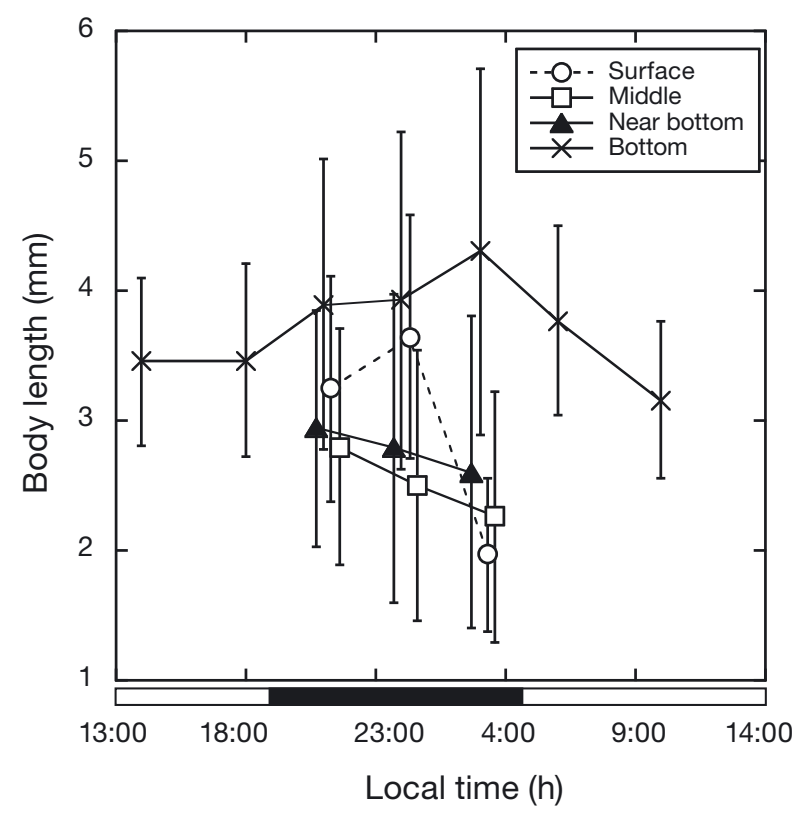

Fig. 3. Spatial and diel variations in mean $( \pm \mathrm{SD})$ body length of Orientomysis mitsukurii in a sandy shore environment in Ukedo-hama. The nighttime period is indicated by the black area under the $x$-axis (local time) distinct differences between daytime and nighttime (Fig. 5, Table 1). During the daytime, almost all stomach contents were composed of unidentified amorphous materials (Fig. 5A,B). Stomach contents during the daytime also included small amounts of planktonic/benthic diatom frustules (Fig. 5C), as well as fragments of crustacean exoskeletons (Table 1). In contrast, the stomach contents of mysids collected at night were exclusively packed with fragments of the planktonic diatom Rhizosolenia spp. (Fig. 4D,E), while small quantities of unidentified materials were also observed in all individuals (Table 1). L. danicus (Fig. 5F) and other diatom frustules were secondarily important food items (Table 1). Fragments of crustaceans were also found in the stomach contents at nighttime, but these were not dominant (Table 1).

Elemental analysis by EDS of the daytime samples revealed that the unidentified materials largely consisted of clay minerals that contained a great deal of $\mathrm{Al}$ as well as Si (Table 2), suggesting that the mysid diet during the daytime contained a large amount of sediment. The elemental analysis also confirmed the nighttime switch of food items to diatoms by an increase in the proportion of $\mathrm{Si}$ (Table 2). Overall, the stomach content and elemental analyses revealed that there was no significant difference in the proportions of food items collected during the night between the bottom and surface layers (Fisher's exact test, $\mathrm{p}>0.05$ ).

\section{Bottle incubation experiments}

On average, $88 \%$ of the diatom pigments were destroyed after ingestion by O. mitsukurii (Table 3). No significant difference in the pigment destruction rate existed between the 2 experimental dates ( $t$-test, $p>0.05$, values were arcsine-transformed).

The clearance rates of $O$. mitsukurii for the diatom $L$. danicus obtained from the bottle incubation experiment in the laboratory varied with diatom concentration (Fig. 6A). Although the clearance rates of individual $O$. mitsukurii varied from $26-57 \mathrm{ml} \mathrm{h}^{-1}$ at the lowest diatom concentration (ca. 50 cells ml$^{-1}$ ), the rates became constant at approximately $5-7 \mathrm{ml}$ $\mathrm{h}^{-1}$ at higher concentrations ( $>300$ cells ml $^{-1}$ ), with no saturation at an extremely high diatom concentration (Fig. 6B). Conversion of the grazing rates into carbon ingestion rates revealed that individual $O$. mitsukurii are able to ingest, on average, $1.6 \mu \mathrm{gC} \mathrm{h}^{-1}$ in diatom concentrations $<300$ cells ml $^{-1}$ (Fig. $6 \mathrm{C}$ ), which corresponded with the maximum diatom concentration observed in the field. 

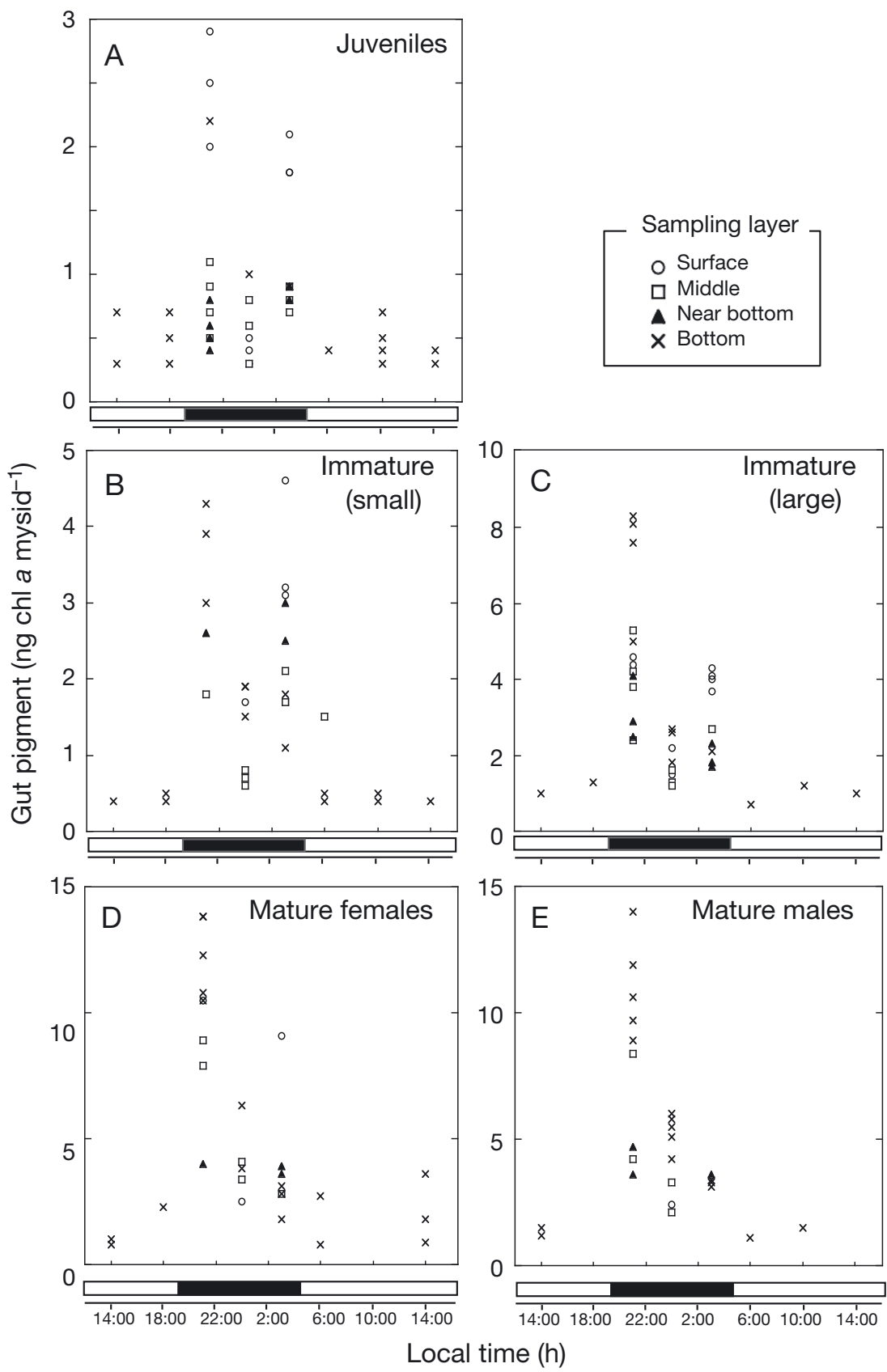

Fig. 4. Spatial and diel variations in gut pigment contents of different developmental stages of Orientomysis mitsukurii in a sandy shore environment in Ukedo-hama. (A) Juveniles (1.9-3.4 mm in body length), (B) small immature $(3.7-4.8 \mathrm{~mm}),(C)$ large immature $(5.3-6.9 \mathrm{~mm})$, (D) adult females $(7.1-7.9 \mathrm{~mm})$, and $(\mathrm{E})$ adult males $(7.0-7.9 \mathrm{~mm})$. Nighttime periods are indicated by the black area under the $x$-axis (local time)

SEM observations revealed that the sedimented POM was composed of loosely aggregated particles (Fig. 7A,B). The particles were variable in size, and were approximately 50-100 $\mu \mathrm{m}$ in width (Fig. 7B). Although frustules of benthic and planktonic diatoms were occasionally observed, the particles mostly consisted of unidentified materials (Fig. 7C,D). A chemical composition analysis revealed that ash accounted for $76 \%$ of the total dry weight of sedimented POM, while organic carbon and nitrogen comprised approximately 1 and $0.2 \%$ of the total dry mass, respectively, indicating that the nutritional value of the sedimented POMutilised in the experiment was low. O. mitsukurii egestion rates varied between 6 and $21 \mu \mathrm{gAFDWmysid}{ }^{-1} \mathrm{~h}^{-1}$, withanaverage of $15.3 \mu \mathrm{gAFDW}$ mysid $^{-1} \mathrm{~h}^{-1}$ (Table 4). The mean ingestion rate of sedimented POM was estimated as being 22.8 $\mu$ gAFDW mysid $^{-1} \mathrm{~h}^{-1}$, which corresponded to a carbon ingestion rate of 1.0 $\mu \mathrm{gC}$ mysid $^{-1} \mathrm{~h}^{-1}$ (Table 4).

\section{Daily food intake and assimilation}

Based on a pigment destruction rate of $88 \%$, the in situ phytoplankton ingestion rate during the nighttime (12 h) by an adult mysid (6 $\mathrm{mm} \mathrm{BL}$ ) was estimated as being $1.8 \mu \mathrm{gC}$ mysid $^{-1} \mathrm{~h}^{-1}$, resulting in a nocturnal ingestion rate of $21.4 \mu \mathrm{gC}$ mysid $^{-1}$ for $12 \mathrm{~h}$ (Table 5). Results from the bottle incubation experiment with cultured diatoms demonstrated a similar ingestion rate of $19.2 \mu \mathrm{gC}$ mysid $^{-1}$ for $12 \mathrm{~h}$ under the field-environment diatom concentrations $\left(\sim 300 \mathrm{cell} \mathrm{ml}^{-1}\right)$, indicating that gut pigment analysis method is an appropriate method for estimating algal ingestion by $O$. mitsukurii. In the same manner as the gut pigment analysis, the nocturnal algal ingestion rates of small ( $2 \mathrm{~mm} \mathrm{BL}$ ) and medium ( $4 \mathrm{~mm} \mathrm{BL}$ ) mysids were estimated to be 3.5 and $15.3 \mu \mathrm{gC}$ mysid $^{-1}$ for $12 \mathrm{~h}$, respectively (Table 5).

The mean ingestion rate by adult mysids of sedimented POM was $22.8 \mu \mathrm{gAFDW}$ mysid $^{-1} \mathrm{~h}^{-1}$, which corresponded to $1.0 \mu \mathrm{gC}$ mysid $^{-1} \mathrm{~h}^{-1}$. Therefore, daily carbon ingestion of sedimented POM was estimated as $12.3 \mu \mathrm{gC}$, assuming the day length was $12 \mathrm{~h}$ (Table 5). Consequently, the weight-specific carbon ingestion rate by adult individuals $\left(103 \mu \mathrm{gC}\right.$ ind. $\left.{ }^{-1}\right)$ of sedimented POM was $0.12 \mu \mathrm{gC} \mu \mathrm{gC}^{-1}$ for $12 \mathrm{~h}$. We 

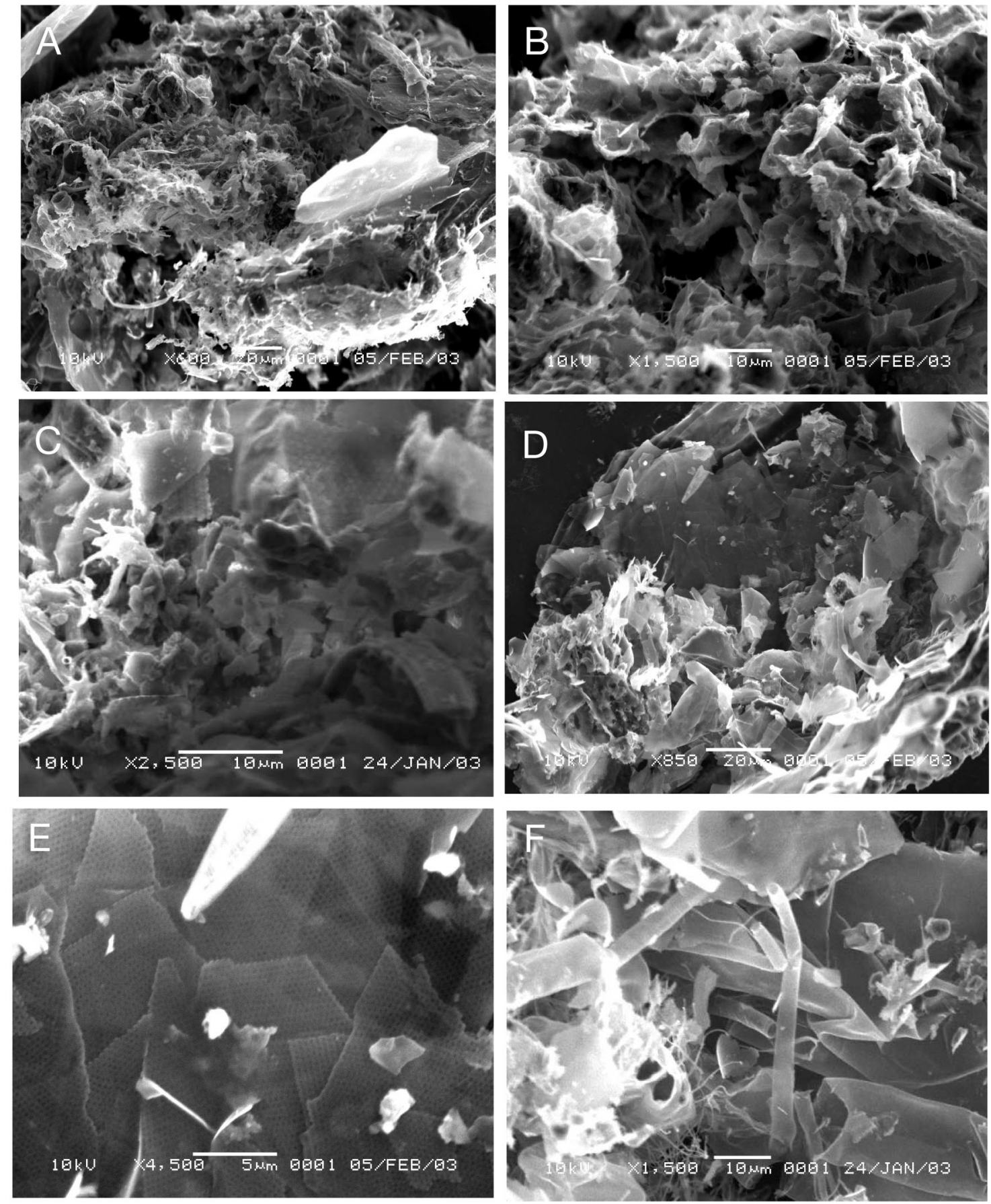

Fig. 5. Scanning electron micrographs of the stomach contents of Orientomysis mitsukurii collected from a sandy shore environment at Ukedo-hama. (A) Whole view of stomach contents of adult female collected from the bottom layer during the daytime, (B) magnified (1500x) view of unidentified materials in stomach contents shown in (A), (C) diatom frustules in stomach contents of immature male collected from bottom layer during the daytime, (D) whole view of stomach contents of adult female collected from the surface layer at night, (E) magnified (4500×) view of planktonic diatom, Rhizosolenia spp. and benthic pennate in stomach contents shown in (D), and (F) Leptocylindrus danicus and unidentified crustacean components in stomach contents of adult male collected from the bottom layer at night

applied a specific ingestion rate for small $(2 \mathrm{~mm} \mathrm{BL})$ and medium (4 mm BL) O. mitsukurii individuals, because mysids were found just above the bottom during the daytime regardless of developmental stage. Consequently, ingestion rates of sedimented POM by small and medium-sized mysids were esti- 
Table 1. Frequency of occurrence of food items in the stomachs of Orientomysis mitsukurii collected from Ukedo-hama in July 2001

\begin{tabular}{|c|c|c|c|c|c|c|c|c|}
\hline \multirow{2}{*}{$\begin{array}{l}\text { Sampling } \\
\text { period }\end{array}$} & \multirow{2}{*}{ Habitat } & \multirow{2}{*}{$\begin{array}{c}\text { No. of stomachs } \\
\text { observed }\end{array}$} & \multirow[b]{2}{*}{$\begin{array}{l}\text { Unidentified } \\
\text { materials }\end{array}$} & \multicolumn{4}{|c|}{ Frequency of occurrence of food items (\%) } & \multirow[b]{2}{*}{$\begin{array}{c}\text { Crustacean } \\
\text { fragments }\end{array}$} \\
\hline & & & & $\begin{array}{l}\text { Rhizosolenia } \\
\text { spp. }\end{array}$ & $\begin{array}{c}\text { Leptocylindrus } \\
\text { danicus }\end{array}$ & $\begin{array}{l}\text { Diatom } \\
\text { frustules }\end{array}$ & $\begin{array}{l}\text { Harpacticoid } \\
\text { copepods }\end{array}$ & \\
\hline Day & Bottom & 6 & 100 & 0 & 17 & 67 & 0 & 50 \\
\hline \multirow[t]{2}{*}{ Night } & Surface & 8 & 100 & 100 & 38 & 63 & 13 & 25 \\
\hline & Bottom & 9 & 100 & 78 & 56 & 56 & 0 & 33 \\
\hline
\end{tabular}

Table 2. Results of energy dispersive spectrometry (EDS) analysis of stomach contents of Orientomysis mitsukurii collected from Ukedo-hama in July 2001

\begin{tabular}{|lccccc|}
\hline Sampling & Habitat & No. of & \multicolumn{3}{c|}{ Mean \% area } \\
period & & $\begin{array}{c}\text { stomachs } \\
\text { observed }\end{array}$ & Al & Si & Si/Al \\
\hline Day & Bottom & 6 & 65.5 & 64.1 & 0.98 \\
Night & Surface & 9 & 51.5 & 74 & 1.53 \\
& Bottom & 8 & 52.8 & 74.3 & 1.48 \\
\hline
\end{tabular}

mated to be 0.4 and $3.6 \mu \mathrm{gC}$ mysid $^{-1}$ for $12 \mathrm{~h}$, respectively (Table 5).

To ascertain the relative importance of daily food assimilation, different assimilation efficiencies of 35 and $80 \%$ were assumed for sedimented POM and algal ingestion, respectively. The total daily assimilated carbon levels were 3.0, 13.5, and $21.4 \mu \mathrm{gC}$ for small (2 mm BL), medium (4 mm BL), and large (6 mm BL) mysids, respectively. These values corresponded to $21-80 \%$ of their total body carbon, and were 2.6-5.9 times higher than their metabolic requirements (Table 5). The contribution of algae consumed during the nighttime was generally high,

Table 3. Pigment destruction in Orientomysis mitsukurii with grazing on the cultured diatom Leptocylindrus danicus

\begin{tabular}{|c|c|c|c|c|c|}
\hline Expt ID & $\begin{array}{c}\text { Date } \\
\text { (yyyy/mm/dd) }\end{array}$ & $\begin{array}{l}\text { Total pigment } \\
\text { in the bottle } \\
\quad\left(\mu \mathrm{g} \mathrm{ml}^{-1}\right)\end{array}$ & $\begin{array}{c}\text { Pigment in } \\
\text { mysids } \\
\left(\mu \mathrm{g} 2 \text { ind }^{-1}\right)\end{array}$ & $\begin{array}{c}\text { Actual } \\
\text { grazing } \\
\left(\mu \mathrm{g} 2 \text { ind. }^{-1}\right)\end{array}$ & $\begin{array}{l}\text { Pigment } \\
\text { destruction }\end{array}$ \\
\hline A1 & $2005 / 07 / 15$ & 130.5 & 2.18 & 18.16 & 0.88 \\
\hline A2 & $2005 / 07 / 15$ & 129.2 & 1.97 & 20.86 & 0.91 \\
\hline A3 & $2005 / 07 / 15$ & 124.6 & 3.42 & 30.02 & 0.89 \\
\hline A4 & $2005 / 07 / 15$ & 132.3 & 3.51 & 14.62 & 0.76 \\
\hline B1 & 2005/08/19 & 183.7 & 5.48 & 51.93 & 0.89 \\
\hline B2 & $2005 / 08 / 19$ & 194.1 & 2.65 & 31.20 & 0.91 \\
\hline B3 & $2005 / 08 / 19$ & 150.6 & 7.44 & 118.15 & 0.94 \\
\hline B4 & 2005/08/19 & 187.9 & 2.10 & 43.68 & 0.95 \\
\hline \multirow[t]{2}{*}{ B5 } & $2005 / 08 / 19$ & 196.4 & 4.51 & 26.62 & 0.83 \\
\hline & & & & Mean & 0.88 \\
\hline
\end{tabular}

but gradually decreased from 95 to $80 \%$ of the daily carbon assimilation with increasing BL (Table 5). The sedimented POM carbon taken during the daytime accounted for only a minor proportion of the total daily carbon assimilation, i.e. 5-20\%.

\section{Stable isotope ratios}

The mean stable isotopic signatures of $O$. mitsukurii individuals collected from Ara-hama during October were $-16.3 \%$ \% $( \pm 0.4)$ and $9.8 \%$ o $( \pm 0.0)$ for $\delta^{13} \mathrm{C}$ and $\delta^{15} \mathrm{~N}$, respectively. Orientomysis tamurai and Synchelidium sp., which are benthic peracarid crustaceans, exhibited slightly enriched $\delta^{15} \mathrm{~N}$ values, while their $\delta^{13} \mathrm{C}$ values were almost the same or slightly lower than in O. mitsukurii (Fig. 8). Nitrogen stable isotopic signatures in the carnivorous sand shrimp Crangon sp. were approximately $2 \%$ higher than in O. mitsukurii. Stable isotopic signatures of seston collected from $0.5 \mathrm{~m}$ above the bottom were $-21.4 \%$ o $( \pm 0.2)$ and $6.9 \%$ o $( \pm 0.8)$ for $\delta^{13} \mathrm{C}$ and $\delta^{15} \mathrm{~N}$, respectively (Fig. 7), which are similar values to those reported in planktonic diatoms from the nearest estuary during the summer (Ito 2002). The isotopic signature of sedimentary organic matter as reported by Ganbe et al. (2014) had considerably lower values of both carbon and nitrogen than did seston collected from $0.5 \mathrm{~m}$ above the bottom layer in the present study (Fig. 8).

\section{DISCUSSION}

Orientomysis mitsukurii exhibited diel changes in its vertical distribution. Diel changes in both vertical and horizontal distributions are well known in 

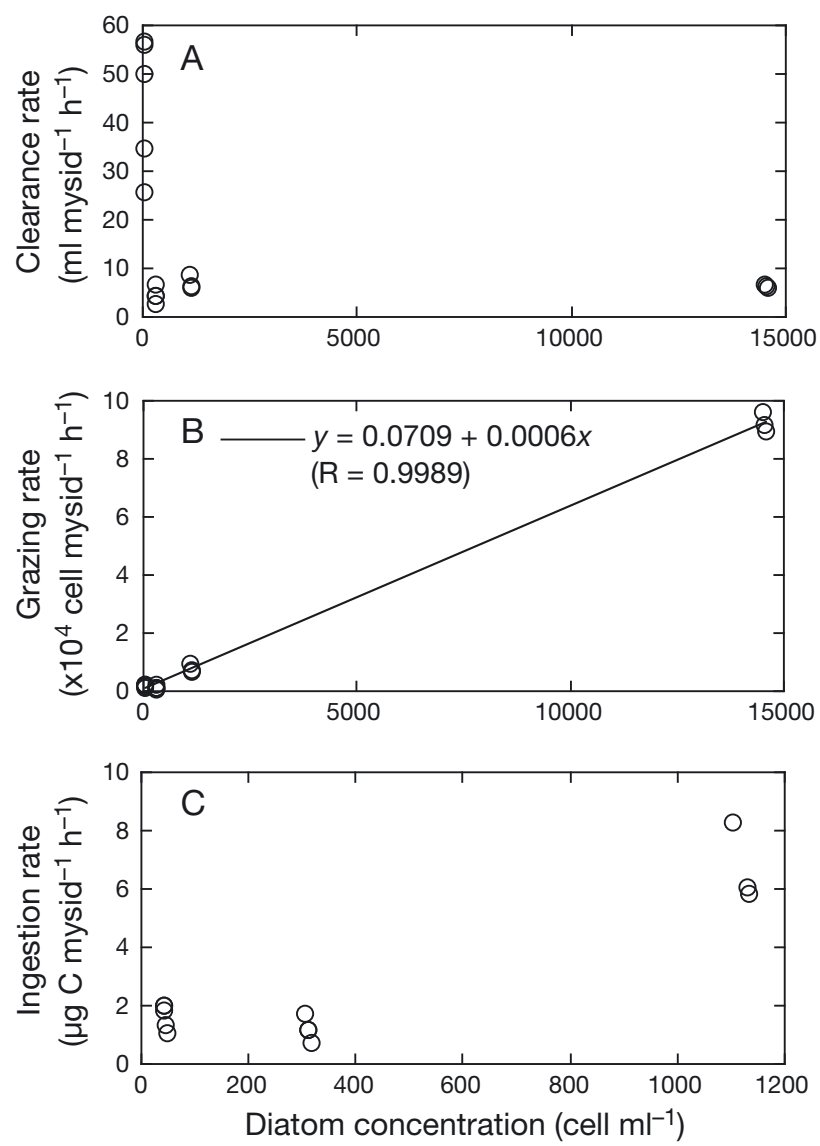

Fig. 6. Laboratory grazing experiments of Orientomysis mitsukurii on the planktonic diatom Leptocylindrus danicus as food. (A) Clearance rate, (B) grazing rate, and (C) carbon ingestion rate as a function of diatom concentration. Note the different scale of the $x$-axis in (C)

many coastal mysid species (Yamada et al. 1998a, Jumars 2007) and are often associated with diel shifts in feeding habits (Takahashi 2004), as was observed in O. mitsukurii in the present study. The field sampling and laboratory experiments indicated that through vertical migration, O. mitsukurii accesses 2 different types of food, planktonic diatoms and sedimented POM, which have different nutritional values.

During the daytime, O. mitsukurii individuals consistently remained within $40 \mathrm{~cm}$ of the bottom and most of their stomach contents were composed of unidentified materials, as previously reported by Yamada et al. (1995). Although diatoms were abundantly distributed at $0.5 \mathrm{~m}$ above the bottom at the study site, these food items were not frequently observed in the stomach contents, except for a few frustules. In the field, Yamada et al. (1998a) reported that O. mitsukurii individuals continuously swim in dense aggregations within $0-20 \mathrm{~cm}$ of the bottom during the daytime. In addition, it has been reported in the laboratory study that during the daytime, they often seize particles, such as sand grains, from the bottom in order to graze on the organic matter on the grain's surface (Yamada 2000). These observations suggest that $O$. mitsukurii does not actively forage in the water column during the daytime, but remains very close to the bottom to search for organic matter deposited on the seafloor. This notion is supported by their stomach contents during the daytime, which contained a large amount of clay minerals, indicating that $O$. mitsukurii ingests food items that contain bottom sediment. Therefore, we conclude that during the daytime, O. mitsukurii ingests sedimented POM that consists of inorganic matter (ash) and a few biogenic particles such as diatoms, though their contribution to the daily carbon assimilation is low.

Sedimented POM appeared as loosely aggregated particles, and it is probable that the majority of these were detrital flocculent materials. In a study by Droppo (2001), detrital flocculent material was observed as a complex matrix of microorganisms (generally bacteria), organic particles (e.g. detritus, extracellular polymers, and cellular debris) and inorganic particles (e.g. clays and silts) with substantial interfloc spaces (pores). It has been suggested that detrital flocculent materials constitute an important component of the detrital food chain in coastal ecosystems, although their origins and chemical compositions vary depending on the environment (Neto et al. 2006). Fockedey \& Mees (1999) reported that flocculent materials are dominant in the stomachs of Neomysis integer individuals in European estuaries, although their nutritional value seems to be low due to the dominance of clay minerals, as shown in this study. Although the dynamics of flocculent material on sandy shores have not been ascertained in detail, particle formation could involve hydrodynamic processes near the sea bottom.

The main diet of $O$. mitsukurii during the night changed to planktonic diatoms, and this was reflected by an increase in gut pigment contents. $O$. mitsukurii generally swam up into the water column at night, although the intensity of its upward movement progressively decreased with growing body size and the majority of the population (consisting of large individuals) remained within $40 \mathrm{~cm}$ of the bottom at night. Yamada et al. (1998a) also reported a slight upward shift in the distribution of O. mitsukurii, from $0-20 \mathrm{~cm}$ above the bottom during the daytime to 20-60 $\mathrm{cm}$ at night. Because diatoms were always abundant at the study site, particularly in the lower layers of the water column, such nocturnal 

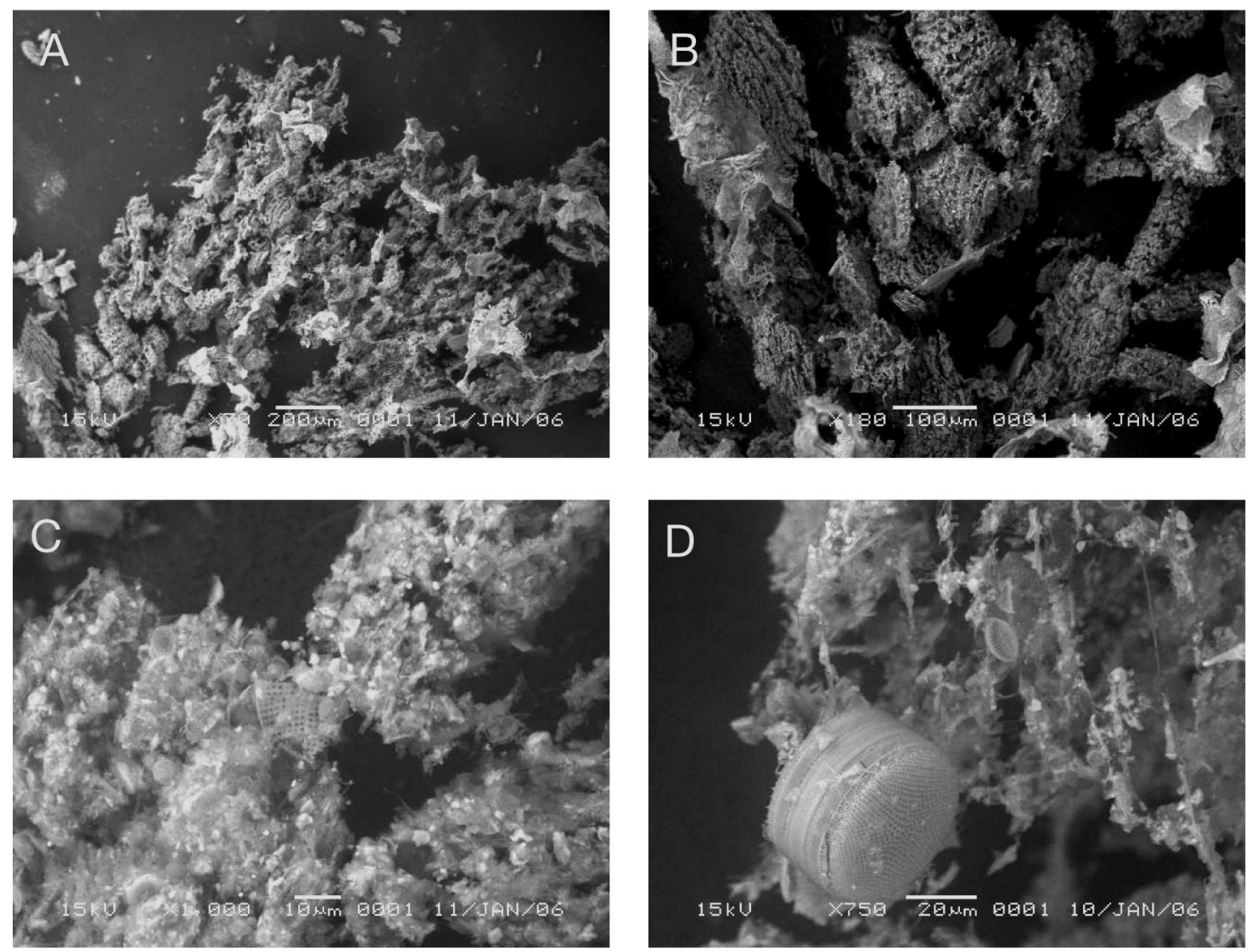

Fig. 7. Scanning electron micrographs of sedimented particulate organic matter (POM) collected from just above the bottom of a sandy shore environment in Ara-hama. (A) Whole view of sedimented POM, (B) magnified (180x) view of sedimented POM shown in (A), (C) diatom frustules and unidentified materials in sedimented POM, and (D) planktonic centric diatom Thalassiosira sp. and benthic diatom Cocconeis sp. in sedimented POM with substantial inter-floc spaces (pores) within the particles

Table 4. Egestion experiment on the sedimented particulate organic matter (POM) with Orientomysis mitsukurii. Ingestion rates were calculated based on egestion rates (see 'Bottom incubation experiments' for details)

\begin{tabular}{|c|c|c|c|c|c|}
\hline Expt ID & $\begin{array}{c}\text { Date } \\
\text { (yyyy/mm/dd) }\end{array}$ & $\begin{array}{l}\text { POM conc. } \\
\left(\mu \mathrm{CC}^{-1}\right)\end{array}$ & $\begin{array}{c}\text { Egestion rate } \\
\left(\mu \mathrm{gAFDW} \text { ind. }{ }^{-1} \mathrm{~h}^{-1}\right)\end{array}$ & $\begin{array}{l}\text { POM ingestion rate } \\
\left(\mathrm{mgAFDW} \text { ind }{ }^{-1} \mathrm{~h}^{-1}\right)\end{array}$ & $\begin{array}{c}\text { Carbon ingestion rate of POM } \\
\qquad\left(\mu \mathrm{gC} \text { ind } .^{-1} \mathrm{~h}^{-1}\right)\end{array}$ \\
\hline $\mathrm{C} 1$ & $2005 / 10 / 07$ & 668 & 21.0 & 31.4 & 1.4 \\
\hline $\mathrm{C} 2$ & $2005 / 10 / 07$ & 668 & 19.0 & 28.4 & 1.3 \\
\hline C3 & $2005 / 10 / 07$ & 466 & 11.0 & 16.4 & 0.7 \\
\hline $\mathrm{C} 4$ & $2005 / 10 / 07$ & 466 & 17.0 & 25.4 & 1.1 \\
\hline C5 & $2005 / 10 / 07$ & 466 & 6.0 & 9.0 & 0.4 \\
\hline C6 & $2005 / 10 / 08$ & 585 & 21.0 & 31.4 & 1.4 \\
\hline $\mathrm{C} 7$ & $2005 / 10 / 08$ & 585 & 6.0 & 9.0 & 0.4 \\
\hline $\mathrm{C} 8$ & $2005 / 10 / 08$ & 585 & 21.0 & 31.4 & 1.4 \\
\hline Mean & & & 15.3 & 22.8 & 1.0 \\
\hline
\end{tabular}

emergence patterns of O. mitsukurii are probably adaptive. Intensive feeding on diatoms at night has often been observed in studies of mysids that inhabit sandy shore regions (Webb et al. 1987, 1988, Wooldridge 1989). O. mitsukurii could exploit such an environment because the physical environment of the sandy shore and its characteristic flow regime results in the accumulation of microalgae (Wooldridge 1989, Webb \& Wooldridge 1990).

Within the O. mitsukurii population, active emergence into the water column at night was more evident in small individuals than in larger ones. As the abundance of juveniles at the surface layer at 03:00 h concurrently occurred with an increase in mean BL 

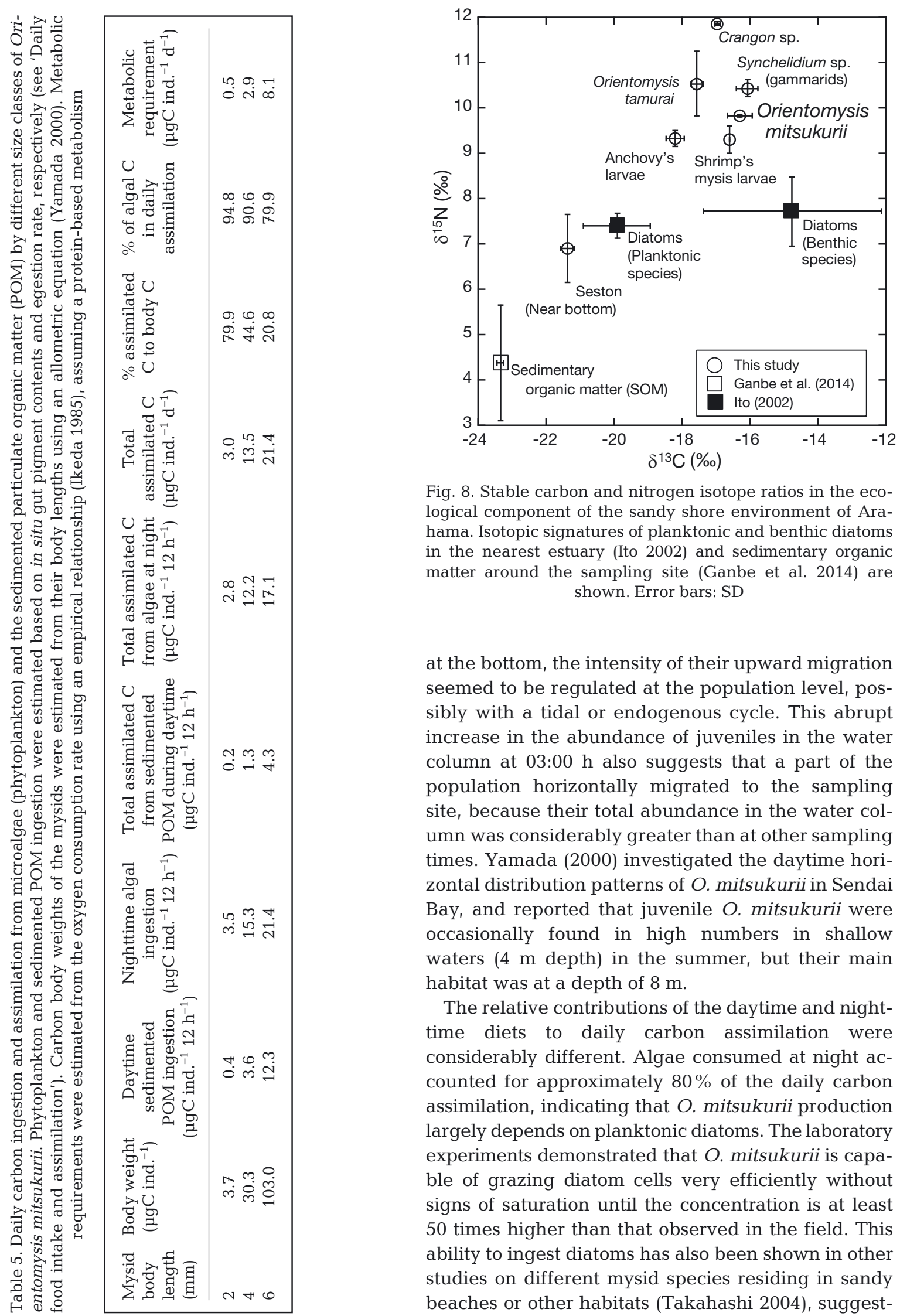

Fig. 8. Stable carbon and nitrogen isotope ratios in the ecological component of the sandy shore environment of Arahama. Isotopic signatures of planktonic and benthic diatoms in the nearest estuary (Ito 2002) and sedimentary organic matter around the sampling site (Ganbe et al. 2014) are shown. Error bars: SD

at the bottom, the intensity of their upward migration seemed to be regulated at the population level, possibly with a tidal or endogenous cycle. This abrupt increase in the abundance of juveniles in the water column at 03:00 $\mathrm{h}$ also suggests that a part of the population horizontally migrated to the sampling site, because their total abundance in the water column was considerably greater than at other sampling times. Yamada (2000) investigated the daytime horizontal distribution patterns of $O$. mitsukurii in Sendai Bay, and reported that juvenile O. mitsukurii were occasionally found in high numbers in shallow waters ( $4 \mathrm{~m}$ depth) in the summer, but their main habitat was at a depth of $8 \mathrm{~m}$.

The relative contributions of the daytime and nighttime diets to daily carbon assimilation were considerably different. Algae consumed at night accounted for approximately $80 \%$ of the daily carbon assimilation, indicating that $O$. mitsukurii production largely depends on planktonic diatoms. The laboratory experiments demonstrated that $O$. mitsukurii is capable of grazing diatom cells very efficiently without signs of saturation until the concentration is at least 50 times higher than that observed in the field. This ability to ingest diatoms has also been shown in other studies on different mysid species residing in sandy beaches or other habitats (Takahashi 2004), suggest- 
ing that the suspension feeding ability of mysids has significant nutritional potential when mysids encounter high concentrations of suspended small food items. Conversely, the contribution of sedimented POM to daily carbon assimilation was relatively low (5-20\%) because of its lower nutritional value. Nevertheless, the daily assimilation of sedimented POM still accounted for $31-53 \%$ of the minimum carbon requirement to maintain mysid metabolism. This indicates that sedimented POM contributes substantially to the basic energy requirements for mysid survival and growth, particularly when food items in the water column decrease in quantity.

The results of the present study also indicate that the relative importance of algae and sedimented POM varies through ontogeny, i.e. small individuals are more dependent on algae in the water column than adults. This appears to be related to small individuals' nocturnal migration pattern of swimming up into the water column more often than large individuals. Although nocturnal emergence in the water column has been suggested to be an adaptation for horizontal dispersal because mysids lack a planktonic larval stage (Alldredge \& King 1980), the ontogenetic change in food preference could be related to the active swimming behaviour of young mysids. For example, the differential ability to utilise relatively large $(>100 \mu \mathrm{m})$ sedimented POM may be caused by ontogenetic differences in nocturnal foraging, because mysid mouthpart morphology changes with growth (Jerling \& Wooldridge 1994). A differential vulnerability to visual predators may also explain differences in nocturnal swimming activity, because small size is effective in preventing prey detection by visual feeders such as pelagic fish, under low light conditions (Robertson \& Howard 1978, Takahashi et al. 2004). Therefore, the low vulnerability of small individuals at night could not only increase foraging for phytoplankton in the water column but also increase dispersal through horizontal migration as found in this study.

Differential utilisation of daytime and nighttime food by $O$. mitsukurii was confirmed by the results of the stable isotopic analysis. The stable nitrogen isotope ratio difference obtained between O. mitsukurii and seston collected from $0.5 \mathrm{~m}$ above the bottom (2.9) was close to the general empirical enrichment factor for one trophic level (3.4; Minagawa \& Wada 1984), indicating that the main food source of O. mitsukurii is planktonic diatoms whose isotopic signatures are similar to those of seston (Ito 2002). However, the slightly lower enrichment factor than the general value of 3.4 indicates some contribution of another food source, possibly sedimentary organic matter, which has a low nitrogen isotopic signature (Ganbe et al. 2014). The stable carbon isotopic analysis results also suggest that benthic diatoms are a food source for $O$. mitsukurii because the stable carbon isotopic signature enrichment factor of 5.0 is too large to assume a simple trophic dependence of $O$. mitsukurii on near-bottom seston including phytoplankton and detritus. This suggests contribution of benthic diatoms, whose carbon isotopic signatures are consistently higher than those in planktonic species (Ito 2002), to the nutrition of the mysids. Benthic diatoms were observed in the water column as well as in the sedimented POM; therefore, they would be a food source when they are abundant regardless of the diel feeding regime of the mysids. This may also explain the increase in gut pigment in adults at night while they were distributed near the bottom.

Overall, the trophic level of O. mitsukurii inferred from the nitrogen isotopic signature was low compared to that of other dominant benthic crustaceans present in the sandy shore environment, indicating that $O$. mitsukurii is primarily a herbivore and a typical secondary producer, although its stomach contents occasionally included detritus and animal prey items. The utilisation of a primary producer, i.e. phytoplankton, as a main food item would be beneficial for maintaining the high abundances of $O$. mitsukurii populations from the viewpoint of ecological transfer efficiency. Moreover, ingestion of diatoms is advantageous in maintaining their populations because diatoms contain a large amount of polyunsaturated fatty acids that are essential compounds for the reproductive success of $O$. mitsukurii (Yamada et al. 1995). Sedimented POM accounts for only a minor proportion of the daily carbon assimilation needs, yet it provides an alternative food source for maintaining high abundance, particularly during the winter when the phytoplankton productivity decreases.

In conclusion, the efficient utilisation of food items from 2 different origins ensures that high abundance of O. mitsukurii populations is maintained in the study area throughout the year. Because the availability of both food items would not change dramatically through the day, we believe that the diel switch between food items results from habitat selection that might be related to predator avoidance. Therefore, diel switching between food items by O. mitsukurii results from adaptations that optimise food intake while avoiding visual predation, which also helps to explain its high abundance. Another possible factor that regulates the food utilisation patterns of $O$. mitsukurii is seasonal variations in surface pro- 
duction, which in turn would affect competition with conspecifics in the water column. For a greater understanding of the effects of environmental variability on mysid populations, detailed investigations of their behavioural adaptations such as gregariousness near the bottom during the daytime (Yamada et al. 1998a) and retention of the population within the sandy shore during nighttime, in relation to food distributions and hydrodynamic disturbances are required.

Acknowledgements. We thank the captain and crew of the fishing boat 'Daigo-chosei maru' and Y. Masuda for field sampling in Ukedo, Fukushima. We are also grateful to Y. Kurita, S. Uehara, and H. Sugisaki for their cooperation with field sampling in Arahama, Miyagi, and to G. Takeda and K. Yamada for their assistance with the SEM observation. K. Kawanobe helped count phytoplankton in the field. The present study was funded by Gyojyo-Seisannryoku from the Ministry of Agriculture, Forestry and Fisheries and a Grant-in-Aid for Scientific Research (B) from the Ministry of Education, Science, Sports and Culture to K.T. (24310007).

\section{LITERATURE CITED}

Alldredge AL, King JM (1980) Effects of moonlight on the vertical migration patterns of demersal zooplankton. J Exp Mar Biol Ecol 44:133-156

Cartes JE, Papiol V, Guijarro B (2008) The feeding and diet of the deep-sea shrimp Aristeus antennatus off the Balearic Islands (Western Mediterranean): influence of environmental factors and relationship with the biological cycle. Prog Oceanogr 79:37-54

Cartes JE, Hidalgob M, Papiola V, Massutíc E, Morantac J (2009) Changes in the diet and feeding of the hake Merluccius merluccius at the shelf-break of the Balearic Islands: influence of the mesopelagic-boundary community. Deep Sea Res I 56:344-365

Dagg MJ, Grill DW (1980) Natural feeding rates of Centropages typicus females in the New York Bight. Limnol Oceanogr 25:597-609

Droppo IG (2001) Rethinking what constitutes suspended sediment. Hydrol Processes 15:1551-1564

Fockedey N, Mees J (1999) Feeding of the hyperbenthic mysid Neomysis integer in the maximum turbidity zone of the Elbe, Westerschelde and Gironde estuaries. J Mar Syst 22:207-228

Froneman PW (2001) Feeding ecology of the mysid, Mesopodopsis wooldridgei, in a temperate estuary along the eastern seaboard of South Africa. J Plankton Res 23: 999-1008

Frost BW (1972) Effects of size and concentration of food particles on the feeding behavior of the marine planktonic copepod Calanus pacificus. Limnol Oceanogr 17:805-815

Ganbe S, Oota H, Suzuki N, Ito K, Sasaki K, Inomata K, Nakagawa R (2014) Presumption of sediment movement in Sendai Bay caused by Pacific coast of Tohoku earthquake tsunami, according to comparison of $\mathrm{C}, \mathrm{N}$ quantity and stable isotope ratio. Miyagi Pref Rep Fish Sci 14:1-10 (in Japanese)

Ikeda T (1985) Metabolic rates of epipelagic marine zoo- plankton as a function of body mass and temperature. Mar Biol 85:1-11

Ito $\mathrm{K}$ (2002) Carbon and nitrogen isotope rations of planktonic and benthic diatoms. Jap J Limnol 63:166-168 (in Japanese)

* Iwamoto Y, Narita Y, Tsuda A, Uematsu M (2009) Single particle analysis of oceanic suspended matter during the SEEDS II iron fertilization experiment. Mar Chem 113: 212-218

* Jerling HL, Wooldridge TH (1994) Comparative morphology of the feeding appendages of four mesozooplankton species in the Sunday River estuary. S Afr J Zool 29:252-257

Johnston NT, Lasenby DC (1982) Diet and feeding of Neomysis mercedis Holmes (Crustacea, Mysidacea) from the Fraser River Estuary, British Columbia. Can J Zool 60: 813-824

Jumars PA (2007) Habitat coupling by mid latitude, subtidal marine mysids: import-subsidized omnivores. Oceanogr Mar Biol Annu Rev 45:89-138

Katayama S, Watanabe S, Fukuda M (2008) The production structure of demersal fish assemblages in sandy shallow areas of Sagami Bay. Bull Jpn Soc Sci Fish 74:36-44

Latour RJ, Gartland J, Bonzek CF, Johnson RA (2008) The trophic dynamics of summer flounder (Paralichthys dentatus) in Chesapeake Bay. Fish Bull 106:47-57

Lehtiniemi M, Nordström H (2008) Feeding differences among common littoral mysids, Neomysis integer, Praunus flexuosus and P. inermis. Hydrobiologia 614:309-320

Mackas D, Bohrer R (1976) Fluorescence analysis of zooplankton gut contents and an investigation of diel feeding patterns. J Exp Mar Biol Ecol 25:77-85

Mauchline J (1980) The biology of mysids. Adv Mar Biol 18: 1-369

Minagawa M, Wada E (1984) Stepwise enrichment of ${ }^{15} \mathrm{~N}$ along food chains: further evidence and the relation between $\delta^{15} \mathrm{~N}$ and animal age. Geochim Cosmochim Acta 48:1135-1140

Möllmann C, Kornilovs G, Fetter M, Köster FW (2004) Feeding ecology of central Baltic Sea herring and sprat. J Fish Biol 65:1563-1581

MSA (Maritime Safety Agency) (2001) Tide tables, Vol. 1: Japan and its vicinities. MSA, Tokyo

Neto RR, Mead RN, Louda JW, Jaffé R (2006) Organic biogeochemistry of detrital flocculent material (floc) in a subtropical, coastal wetland. Biogeochemistry 77:283-304

Perissinotto R (1992) Mesozooplankton size-selectivity and grazing impact on the phytoplankton community of the Price Edward Archipelago (Southern Ocean). Mar Ecol Prog Ser 79:243-258

Ritz DA (2008) Gut residence time in pelagic crustaceans. J Mar Biol Assoc UK 88:65-67

Roast SD, Widdows J, Jones MB (2000) Egestion of the estuarine mysid Neomysis integer (Peracarida: Mysidacea) in relation to a variable environment. J Exp Mar Biol Ecol 245:69-81

Robertson AI, Howard RK (1978) Diel trophic interactions between vertically migrating zooplankton and their fish predators in an eelgrass community. Mar Biol 48:207-213

Suzuki R, Ishimaru T (1990) An improved method for the determination of phytoplankton chlorophyll using $\mathrm{N}, \mathrm{N}$ dimethylformamide. J Oceanogr 46:190-194

Suzuki T, Shibata M, Tanaka K, Tsuchida K, Toda T (1995) A new drying method: low-vacuum SEM freeze drying and its application to plankton observation. Bull Plankton Soc Japan 42:53-62 (in Japanese with English Abstract) 
Takahashi K (2004) Feeding ecology of mysids in freshwater and marine coastal habitats: a review. Bull Plankton Soc Japan 51:46-72 (in Japanese with English Abstract)

Takahashi K, Hirose T, Azuma N, Kawaguchi K (2004) Diel and intraspecific variation in vulnerability of the beach mysid, Archaeomysis kokuboi Ii, 1964, to fish predators. Crustaceana 77:717-728

Takahashi K, Nagao N, Taguchi S (2015) Diel distribution and feeding habits of Neomysis mirabilis under seasonal sea ice in a subarctic lagoon of northern Japan. Aquat Biol 23:183-190

Toda T, Suh HL, Nemoto T (1989) Dry fracturing: a simple technique for scanning electron microscopy of small crustaceans and its application to internal observations of copepods. J Crust Biol 9:409-413

Tomiyama T, Watanabe M, Kawata G, Ebe K (2011) Postrelease feeding and growth of hatchery-reared Japanese flounder Paralichthys olivaceus: relevance to stocking effectiveness. J Fish Biol 78:1423-1436

Tomiyama T, Uehara S, Kurita Y (2013) Feeding relationships among fishes in shallow sandy areas in relation to stocking of Japanese flounder. Mar Ecol Prog Ser 479: 163-175

Utermöhl H (1958) Zur Vervollkommnung der qualitativen Phytoplankton-Methodik. Mitt Int Ver Theor Angew Limnol 9:1-38

*Viherluoto M, Viitasalo M (2001) Temporal variability in functional responses and prey selectivity of the pelagic mysid, Mysis mixta, in natural prey assemblages. Mar Biol 138:575-583

Vilas C, Drake P, Fockedey N (2008) Feeding preferences of estuarine mysids Neomysis integer and Rhopalophthalmus tartessicus in a temperate estuary (Guadalquivir Estuary, SW Spain). Estuar Coast Shelf Sci 77:345-346

Webb P, Wooldridge TH (1990) Diel horizontal migration of

Editorial responsibility: Bernard Sainte-Marie, Mont-Joli, Quebec, Canada
Mesopodopsis slabberi (Crustacea: Mysidacea) in Algoa Bay, southern Africa. Mar Ecol Prog Ser 62:73-77

WWebb P, Perissinotto R, Wooldridge TH (1987) Feeding of Mesopodopsis slabberi (Crustacea, Mysidacea) on naturally occurring phytoplankton. Mar Ecol Prog Ser 38: $115-123$

*Webb P, Perissinotto R, Wooldridge TH (1988) Diet and feeding of Gastrosaccus psammodytes (Crustacea, Mysidacea) with special reference to the surf diatom Anaulus birostratus. Mar Ecol Prog Ser 45:255-261

Wooldridge TH (1989) The spatial and temporal distribution of mysid shrimps and phytoplankton accumulations in a high energy surfzone. Vie Milieu 39:127-133

Yamada H (2000) Production ecology of the mysid shrimp Acanthomysis mitsukurii (family Mysidae) as primary food organism of juvenile Japanese flounder. PhD thesis, University of Tokyo (in Japanese)

Yamada H, Nagahora S, Sato K, Musashi T and others (1994) Species composition and distributional pattern of Mysidacea in Pacific Ocean coast of Japan. Bull Tohoku Natl Fish Res Inst 56:57-67

Yamada H, Kawamura T, Takeuchi T, Yamashita Y (1995) Effects of dietary condition on the survival, growth and reproduction of Acanthomysis mitsukurii (Crustacea, Mysidacea). Bull Plankton Soc Japan 42:43-52

Yamada H, Endo Y, Musashi T, Yamashita Y (1998a) Distributions of mysids and larval anchovy as food organisms for juvenile Japanese flounder around artificial flounder reefs. Suisanzosyoku 46:487-494 (in Japanese with English Abstract)

Yamada H, Sato K, Nagahora Y, Kumagai A, Yamashita Y (1998b) Feeding habits of the Japanese flounder Paralichthys olivaceus in Pacific Central waters of Tohoku district, northeastern Japan. Bull Jpn Soc Sci Fish 64: 249-258 (in Japanese with English Abstract)

Submitted: November 2, 2016; Accepted: October 11, 2017 Proofs received from author(s): November 24, 2017 